\title{
Island as urban artifact/archipelago as urban model
}

\author{
Brian McGrath \\ Parsons School of Design, USA \\ mcgrath@newschool.edu
}

\begin{abstract}
This essay introduces islands as urban artifact and archipelagos as urban model in order to deepen the rich interdisciplinary discussion between island and urban studies through the specificity of an architectural analysis of islands as built form and archipelagos as urban systems. Four examples are presented here to demonstrate the use of islands as "urban artifacts" and archipelagos as "urban models" within architecture and urban discourse. Built island artifacts and the widespread use of archipelago as model for urban design have been deployed as apparatuses of political power and social exclusion, often in conflict with ecological systems. Island Studies provides a novel interdisciplinary lens for furthering analyses of the social equity and climate crises imperatives implicit in the use of islands and archipelagos as metaphors in architecture and urban design. In conclusion, the paper links Island Studies and oceanic thinking to the concepts of patch dynamics and the metacity. By reconceiving planetary urbanism as an oceanic rather than terrestrial system, this essay seeks to critically propose the critical and reflective use of island artifacts and archipelago models as designed ecosystems of meaning, inclusion, and belonging within seas of difference.
\end{abstract}

Keywords: archipelago model, ghetto, island artifact, metacity, patch dynamics, refuge, sacred island, social-natural system

https://doi.org/10.24043/isj.140 • Received May 2020, accepted August 2020

(C) Island Studies Journal, 2020

\section{Introduction}

Whether massive engineering projects, such as Kansai Airport, built atop an artificial island in Osaka Bay, or sensitive natural landscape designs, such as Duck Island, a constructed waterfowl sanctuary in the heart of imperial London, built islands are urban artifacts comprising intertwined social and natural systems. Humans have constructed islands for millennia to separate the sacred from profane, healthy from sick, friend from foe, and human from non-human. This essay contributes to the field of Island Studies through its focus on "island as built artifact" and "archipelago as an urban model". While urban island studies are rich with descriptions of the inhabitation and extension of naturally occurring islands (Grydehøj et al., 2015), human built islands and island and archipelago writing in architectural theory have been given less attention. Importantly, this essay employs Island Studies critically to shed light on the use of built islands and archipelago models as strategies of social exclusion, often in conflict with ecological systems. Adding to Grydehøj's critical approach to 
"islandness", that an island is not only in the eye of the beholder, it can also be in the hands of the island and archipelago builder, and the recognition of or decision to make a place as an island or archipelago is culturally and temporally conditioned (Grydehøj \& Casagrande, 2020).

This essay begins with the definition of "island as artifact," utilizing Aldo Rossi's (1982) theory of urban artifacts to understand the use of built islands as structural elements built as part of the "architecture of the city." This architectural definition of 'artifact' is tied with the phenomenology of islands as places and objects of design and their remarkable tie to the history of cities (Grydehøj, 2015a; Grydehøj et al., 2015; Hay, 2006; Johnson, 2020). Rossi describes artifacts in the same way that Hay (2006, pp. 30-32) describes islands: as sites of "collective memory, where the measured pace of human-induced change has the capacity to layer up stories, [...] welding past to present and ensuring a seamless passage of time." There is, then, a vertical or temporal axis to place, as well as the obvious horizontal plane of space (see Figures 1, 2, 3, and 4 for illustrations of four urban territories layered in time and expanding horizontally and vertically in space). The politics of "island as urban artifact" lies in the tension between the solitary subject and the mutuality of cities. Thus, islands as urban artifacts, at their best, are "havens for the collective $[\ldots]$ continually interrogating the privileging of the relationship between the isolated individual and the bounded physical space" (Polack, 1998, cited in Hay 2006, p. 30).

To introduce the concept of island as urban artifact, this essay describes the historical city of Sukhothai, Thailand to demonstrate the symbolic importance of cities designed as islands and with important religious and royal structures set apart as island enclaves. Significantly, while Island Studies privileges natural river, lake, estuary,coastal, and oceanic islands (Grydehøj, 2015a), the city of Sukhothai is a constructed island 400 kilometers inland. Additionally, the heart of the city is occupied by several Buddhist monasteries, which are themselves built on artificial islands. Sacred islands and island symbolism in Asia have been cited in an effort to decolonize Island Studies (Luo \& Grydehøj, 2017). The Kingdom of Thailand, formerly Siam, presents a special case. It is historically defined by islands constructed as mandala power centers of Buddhist polities successively at Sukhothai, Ayutthaya, and Bangkok. Sukhothai represents a form of Sanskrit colonization before European hegemony (Abu-Lughod, 1989) and was a tributary state of the Indianized empire of Angkor, itself later defeated by and under tribute to the kings of Ayutthaya (Cœdès, 1968). Thailand, never colonized by Europe, selfmodernized and remained a sovereign state during the turn of the $20^{\text {th }}$ Century.

Venice is presented here as a second example of an island city as urban artifact in itself as well as constituting an archipelago city. The image of Venice as an island city is, in fact, literally an architectural construction. Renaissance architects designed a network of bridges, walkways, stairs, and public squares to create the unitary pedestrian experience of a singular urban island within a formerly boat-based archipelago city. While Venice has been the subject of much literature in Island Studies (Grydehøj \& Casagrande, 2020), this essay furthers the discussion by examining its architectural evolution over time. Drawing from Italian architectural sources (Mancuso, 2009; Muratori, 1960), Venice is understood as constructed originally as an archipelago of self-sufficient parishes, built in a part of the lagoon where no natural islands previously existed. Venice is a land-reclamation project as much as those described by Adam Grydehøj (2015b) in Making ground, losing space: Land reclamation and urban public space in island cities.

While Island Studies has focused on the decolonizing project of critically challenging the view of islanders as "others", less has been written about the construction of islands of social exclusion within the cities of the West, and, in the case of the Venetian Ghetto, by 
islanders themselves. While the description of islands as places essentially isolated, disconnected, and apart is seen as a stereotype (Grydehøj et al., 2015, p. 8), in the Venetian Ghetto this was a designed fact of life for the controlled exclusion of Jews outside of their marginal economic role in the city. The call for a study of islandness as a state of tension between "openness and closure" (Baldacchino, 2004, p. 274) can be seen in both the connection and separation afforded in Venice's Jewish island ghetto as an urban artifact.

In the third section, this essay examines the rhetorical transfer of the archipelago city from the reality of the Lagoon of Venice, to the imagined "green lagoon" of the walled, ruined, and shrinking city of post-war West Berlin (Hertweck \& Marot, 2013). This essay contextualizes "archipelago as model" by both revealing the origins of the archipelago city in contemporaneous architectural studies of Venice by Muratori, and investigating its (mis)use of archipelago as an urban metaphor in terrestrial contexts. While " $[\mathrm{t}]$ here is a valid and strong case for the archipelagic lens to become [...] a theoretical structure for analyzing the city [...] bringing much-needed sociocultural context and organic flexibility into the existing approaches to urban research" (Grydehøj et al., 2015, p. 9), many architects have used this model uncritically with anti-social and anti-natural consequences. A more critical reflection is needed in architectural theory on the use of archipelago as a relational rather than formal urban model (Pugh, 2013; Stratford et al., 2011).

Recently, island and archipelago form has been used uncritically in architectural theory as a metaphorical model for the design of large objects or "landforms", rather than as aquatic systems (Allen, 2011; Daou \& Pérez-Ramos, 2016). Island Studies critically posits a more reflective approach on both the positive and negative uses of archipelago as urban metaphor (Grydehøj et al., 2015). The use and misuse of meaning, model, and metaphor in interdisciplinary work is helpfully spelled out by ecologists S.T.A. Pickett and M.L. Cadenasso (2007). They differentiate meaning, model, and metaphor successively as "a core meaning or definition, a suite of ways to specify the concept in particular models or applications, and the [...] metaphorical dimension [...] allow[ing] the idea to be communicated" (Pickett \& Cadenasso, 2007, p. 16). I have long worked in collaborative interdisciplinary research with Pickett and Cadenasso, as well as urban designer Victoria Marshall, using shared metaphors and meaning critically, but maintaining different core disciplinary models (McGrath et al., 2007; Marshall et al., 2020).

In its conclusion, the essay returns to Thailand to investigate the tension between the cultural legacy of island as urban artifact in a Buddhist polity to the contemporary idea of archipelago as crypto-colonial urban model (Herzfeld, 2002), in a sprawling industrial area located in the riparian flood zone of the Lower Chao Phraya basin. Archipelagic and oceanic studies emphasize post-colonial readings of the diasporic inhabitants of islands in the Global South (Gómez-Barris \& Joseph, 2019). In the Lower Chao Phraya, the island Buddhist polities of Ayutthaya and Bangkok, like upstream Sukhothai, are located in backwater plains seasonally flooded by monsoon rain. The sacred royal enclaves of Ayutthaya and Bangkok are both islands created by cutting canals at sweeping meanders in the Chao Phraya River. Michael Herzfeld (2012) has theorized the transformation of the royal Rattanakosin Island of Bangkok as a "crypto-colonial dilemma." Over the last five decades, the vast inland aquapelagic assemblage (Hayward, 2015) of the Chao Phraya Delta has been transformed into a patchy landscape of industrial estates, rice paddies, villages, and a sprawling megacity.

Both green and blue, the Lower Chao Phraya today comprises a sprawling urban archipelago of "backwater urbanism" (McGrath, 2014). 
This comprehensive outline of architectural theories of island as urban artifact and archipelago as urban model aligns with the theoretical project of the metacity. Metacity theory forms the basis for an emancipatory project of an archipelago of ecologically and socially activist designed "islands" linking to a new digitally enhanced global imaginary. The metacity emerges in the fragments of an era of global finance, deregulated world trade, volatile clouds of social media, and from an exhaustion of the definitions and meanings in separating the terms city, metropolis, and territory. The metacity was introduced to describe new possibilities for solidarity in our socially complex, spatially heterogeneous, and ecologically mixed urbanized planet (McGrath \& Shane, 2012). The metacity is a political movement appearing within historical settlements, shells of the fragmented industrial metropolis, as well as in new conurbations sprawling across formerly rural and wild territories. Most interestingly, the United Nations (UN) has pejoratively described metacities as polycentric and with diffuse governance without a centralized management apparatus - but for us, this is its strength and its alignment with island and archipelagic thinking (McGrath \& Pickett, 2011). Together, these four sections position "island as urban artifact" and "archipelago as urban model" as ways to imagine a metacity of planetary urbanism not as a terrestrial system of property, but as an oceanic polity of constructed self-sufficient patches, islands, and archipelagos.

\section{Island as urban artifact}

In the important treatise The architecture of the city, Aldo Rossi (1982/1966) draws from multiple disciplines to theorize the collective nature of architecture and urban form. For Rossi (1982/1966), urban artifacts are the ultimate factual evidence of the city as a collective work of art born in a social unconscious, within a specific geographical territory, over time. The architecture of the city achieves a balance between natural and artificial elements as both an object of nature and a subject of culture. City and region, farm and forest are immense repositories of the social organization of human labor. The architecture of the city testifies to our present values as well as constitutes permanence and collective memory (Rossi, 1982/1966). Rossi's arguments that cities are artifacts in themselves and that they contain special areas or urban artifacts within them, coincides with discussions of Island Studies in itself and of urban island dynamics within and between islands. Island cities take various forms as urban artifacts, and small island artifacts at the historical centers of cities are common (Grydehøj et al., 2015). Islands are essential parts of the architecture of cites in projecting power territorially, as a means of defense and offering trade and transportation benefits (Grydehøj, 2015a).

Roland Barthes' (1970) writing about the need to "read" the urban as a signifying space resonate with the early formation of islands as sites of innovative conceptualizations (Baldacchino, 2006). For Barthes (1970, p. 166), scientific geography and especially modern cartography obliterate and censor meaning and signification through "ruthless objectivity." As urban artifacts, islands are complex qualitative objects that are possible to analyze socially and politically, but difficult to completely define in scientific language. Built island form can be read as urban artifacts through Barthes' semiology of the urban as a metalanguage, signifying cultural values as well as social and political aspirations. Similarly, according to DeLoughrey (2001, p. 41), islands comprise a “meta-archipelago.” For Rossi (1982/1966, p. 33), the city can be read as the human achievement par excellence, representing a type of sensory, cognitive, psychological experience "recognizable only to those who have walked through 
the particular building, street, or district. Our conception of an urban artifact is unique to our lived experience in relation to it." Our cities, neighborhoods, and homes are cognitively our islands. The architecture of the city possesses "unequivocal social and cultural power [...] to produce representations of the world through exemplary forms of built reality" (Aureli, 2008, p. 91) and is "an argument against the logic of urbanization (and its instigator, capitalism)" (Aureli, 2008, p. 92). Following are examples of built islands as urban artifacts, material constructions that are shaped by human acts, but which also condition activity and action.

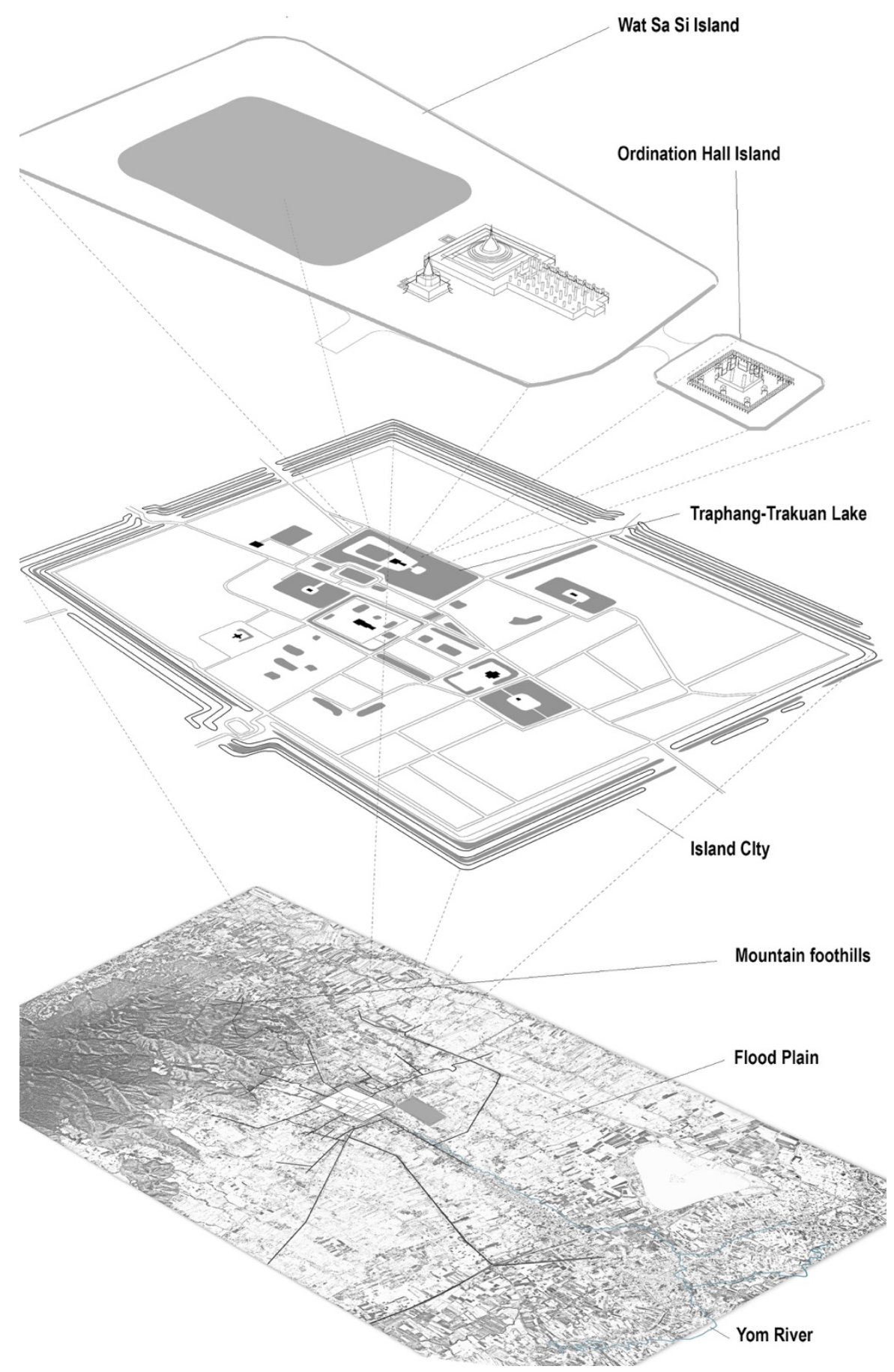

Figure 1: The "three worlds" of Sukhothai: Top, Wat Sa Si; middle, the triple moated royal island city; bottom, Yom River Valley. Illustration: (C) Brian McGrath \& Tommy Yang. 
The walled city of Sukhothai, Thailand, which means "dawn of happiness", is a constructed island built within three concentric levees and moats, close to the foothills of the mountainous northern region of Thailand to the west, and the Yom River, a tributary to Bangkok's Chao Phraya River to the east. During the monsoon season, the mountain rainwater runoff and swelling river transform the flooded plain of the valley into a green lagoon of wet rice paddies. Monasteries built as islands in lakes within the city walls provided a spiritual retreat for meditation practice, but also served to retain monsoon rains and control flooding. The hydrological metabolism is reflected in the political structure of tributary states, where lesser kings send "tribute" to more powerful polities downstream. Sukhothai's royal dynasties, like the imperial Khmers to the east, learned the art of statecraft from diasporic Brahman priests. Sumset Jumsai points to the Angkor's Indic cosmological model: "the king identified himself with Indra's slaying of the serpent-cloud atop Mount Meru, with Vishnu's subjugation of [...] Shiva's symbol of procreation and fertility" (Jumsai, 1998, p. 11). The king is dhamaraja, ruling land and waters from atop Mount Meru. Abstract thought can be seen in the coding of a microcosm and polity of oceans and (is)lands (Jumsai, 1998 p. 11).

Traphang-Trakuan Lake, the largest body of water within the ancient city of Sukhothai, forms the northern boundary of the former palace and the imposing ruins of the royal temple Wat Mahathat (see Figure 1). On religious occasions, the palace entourage would head north from the palace, crossing the lake towards a pair of Sri Lankan styled stupas situated in front of a large reflecting pool to the west. The Viharn, the main congregational hall of the Wat Sa Si monastery, is located in front of the stupa, with a large golden seated Buddha facing east. Further east is another small islet containing the Ubohsot, an ordination, prayer and meditation hall, reserved for the monks who resided in the religious complex. The meditation hall, at the center of the city has a remarkable stillness, the product of careful design. Architectural tools of spatial separation, choreographed sequence and hierarchy of land and water demonstrate the power and metalanguage of built islands as urban artifacts.

Two additional island monasteries were built in their own constructed lakes west and east of the palace compound. To the east, Wat Traphang Thong, the Golden Lake Monastery, is located on its own island near the main eastern gate to the city, and still contains an active community of monks. Wat Traphang Ngoen, the Silver Lake Monastery, like Wat Sa Si, contains an ordination hall on an islet in the middle of another artificial lake. To the north of the royal palace is a fourth island monastery, Wat Traphang So, the temple in the Lime Tree Pond. In total, there are ruins of 26 monasteries within the city walls of ancient Sukhothai, many of them situated on islets within constructed ponds surrounding the king's compound. The island monasteries form a constellation of what Sumet Jumsai (1988, p. 109) calls "water chapels" in his book on the architectural and urban models of the sacred cosmology of the cultural archipelago of Siam and the West Pacific.

The Traibhumi (Three Worlds Cosmography), recopied over the centuries from the Pāli canon and commentaries dated to the Sukhothai Kingdom as far back as 345 A.D., provides the full details of Siamese Buddhist cosmography (Reynolds, 1976). The three worlds are subdivided into 31 levels of karmic attainment, moving from the lowest world of form, sensation and desire, to a middle world free of sensation and desire, and the highest level of formless deities and insensate being who have no needs and wants (Reynolds, 1976). The king, as dhamaraja, represents the highest achievement of merit accumulated in past lives, and lords over his subjects, but also sustains the meditation practice of the monks in the 
surrounding monasteries; meditative cities within the royal city. The three worlds are materially present and ensure distancing between social classes in Sukhothai (see three layers of Figure 1): the world of peasant labor in the fields and villages outside the moats, the ritual performance of a royal and religious elite on their island enclaves, and a third reality, a "metacity", invisible but always present, above and beyond the mundane world of everyday life. Sukhothai is a collective artifact, constituting collective memory and permanence in its signification of a cosmology of three worlds. Its construction technology was born from the indigenous knowledge of rice farmers who reformed the land to manage monsoon water flows for rice cultivation within river valleys but, as a constructed cosmology, the architecture segments social classes through form, space, and materiality.

\section{Venice: island or archipelago city?}

In March of 1516, over the course of three days, several hundred Jews were forcibly "escorted" to their new homes on Ghetto Nuovo (Fortis 2000/1987, p. 18, see Figure 2). The Venetian political council designated the small peripheral island, a place of low value, for the mostly foreign Jewish population, where they could be isolated and controlled. Named for the old copper foundries that had been previously located there, Ghetto Nuovo became a "city in the city" (Mancuso, 2009, p. 28). The island ghetto was secured by two entry bridges with gates that were locked at night but, during the day, the campo's pawn shops and money lenders were visited by many Venetians. The pentagonal shaped island of Ghetto Nuovo is entered by crossing a wooden bridge into a central square, an open "campo", translated as "field", is framed by two colorful L-shaped blocks of houses framing the sky. Sloping roofs channel rainwater, a precious resource in the briny lagoon, to internal courtyards covering storage tanks and to private cisterns on the ground floors (Mancuso, 2009). The Campo Ghetto Nuovo was built atop an underground and impermeable clay cistern. The cisterns were filled with sand containing two cylindrical barrels: one of brick and an inner one of stone that collects rainwater. When examined closely, a Venetian campo can be seen as a stone catch basin shaped to feed rainwater to several carefully placed drains around the periphery. In Ghetto Nuovo, three wells are located in the stone field, and fresh water, after passing through sand-filled caissons for several stages of filtering, was drawn from the bottom of each. This system "constitutes a fundamental element of the island urban landscape" (Mancuso, 2009, p. 18). The campo itself is an exceptional technological device, making each parish island an urban artifact that was inhabitable and self-sufficient.

In spite of the cruelty and indignity of compulsory isolation, descendants of Venice's Jewish Ghetto today celebrate the cultural benefit that resulted from the forced concentration of diverse people from the vast Jewish diaspora and today the Ghetto is an important World Heritage site (Fortis, 2000/1987 p. 17). Restrictions imposed from the outside were "counterbalanced and almost compensated for from inside by the thorough depth of Talmudic studies and interest in mystic interpretation of Scriptures, the faith of the various ethnic groups - German, Italian, Levantine, and Spanish - with the building of different synagogues" (Fortis, 2000/1987, p. 5). Shortly after their confinement to Ghetto Nuovo, the former two-story foundries were quickly extended vertically and subdivided into tiny rooms with complicated winding internal stairs. The community grew over three centuries, attracting additional exiles who occupied two adjacent islands. Each group maintained their 
own religious rites and built 'schools' - meeting, worship and teaching centers within the upper floors of various buildings surrounding the campo, yet hidden from the outside.

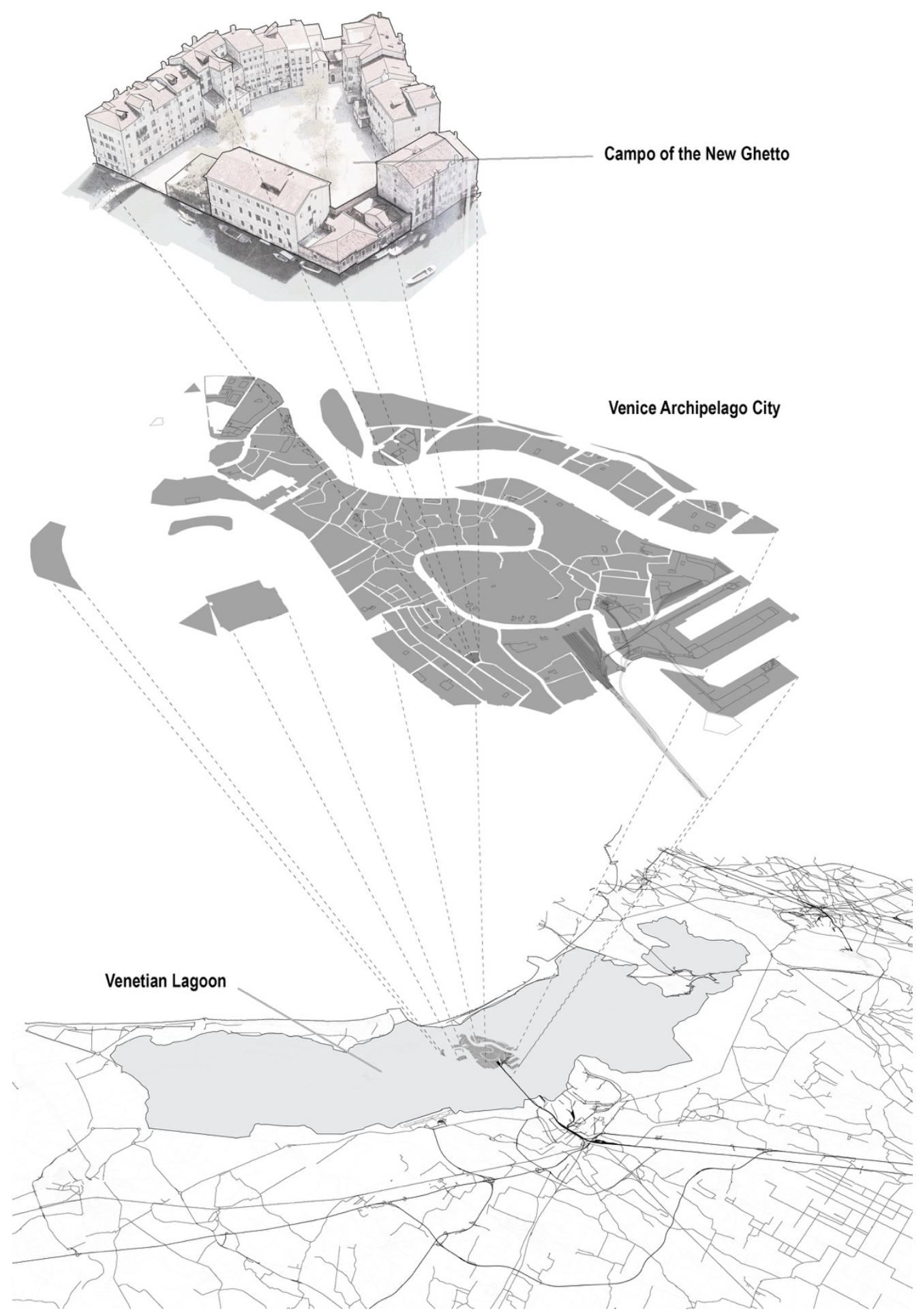

Figure 2: Venice as urban artifact: Top, Ghetto Nuovo; middle, the island city of Venice; bottom, Venetian Lagoon. Illustration: (C) Brian McGrath \& Tommy Yang. 
The Venetian Lagoon is a $55 \times 8 \mathrm{~km}$ arc of backwater north of the Po River Delta, protected from the Adriatic Sea by a long, thin coastal dune. Three mouths open to the sea at Lido, Malamocco, and Chioggia, bringing tidal seawater into the inland sea. There, it meets freshwater which had previously flowed through the Brenta and Piave Rivers before canals diverted the rivers and their sedimentary deposits from the nearby Alps. The Lagoon is not a stable element; it is always in transition in the conflict between the waters that come from the rivers carrying silt, and the water that comes from the sea that flushes to the basin. "If the strength of the rivers wins, the lagoon becomes a pond, if the strength of the sea wins, the lagoon becomes the sea" (Mancuso, 2009, p. XIV). The island city called Venice was constructed on a shifting sandbar formed by the mixture of fresh and sea water in the middle of the swampy lagoon. Traces of its origins can be seen in the S-shaped curve of the Grand Canal, a historical stream that marks where the foundations of the island city were first constructed (Mancuso, 2009, p. 89).

There was no land on which to build Venice; when building the city, the ground was also built (Mancuso, 2009, p. XV). The island city as a whole is an urban artifact that has barely changed its perimeter over time. The wooden city on piles gradually became a city of stone. Renovations and transformations of the buildings were carried out by repairing, reusing, and rebuilding the already built, without ever expanding and crossing the historical edges of the constructed islands. Venice's lesson is not to waste; to make sufficient within one's limits. Venice can therefore be interpreted as an incessant laboratory of technological experiments on island construction, always original and effective, and as the tangible and eloquent response to the problems posed by an unusual and, in many respects, decidedly hostile environment: a response that has generated an architectural form and a particular urban model (Mancuso, 2009, p. 9).

While Venice is understood as an "island city", in other words the entire city is legible as a single urban artifact, through years of careful surveys with his students at the University Venice in the 1950s, Saverio Muratori discovered that originally there was no unitary island city in the lagoon, but a collection of multiple self-sufficient, fortified parishes with little interconnection (Muratori, 1960). Muratori's "operational history" of Venice uncovered a network of separate islands, which constituted the cells of what he called an "urban organism" (1960, p. 14. He identified the highly irregular growth pattern of Venice's "urban tissue" as an organic process of small island cells gradually growing and thickening by filling in the water channels between them. Venice at its origins can now be understood as a group of nuclei, precariously perched on the first indefinite islands barely emerging from the lagoon structure, separated from each other by canals and large water surfaces. Mancuso describes It is a sort of archipelago, in which the emerged lands are, as a whole, certainly less extensive than the water surfaces that separate them (Mancuso, 2009, p. 7). Muratori (1960, p. 29) introduced a new urban model into architectural theory by naming pre- $14^{\text {th }}$ Century Venice the "archipelago city."

Venice's intricately interconnected walkways, bridges, and plazas of today create the image of a unified island city and a singular urban artifact. But this experience, in fact, is fabricated by the Renaissance architects, who designed a pedestrian city with great freedom of access and interconnectivity atop the water-bound urban archipelago. This refashioning of the form of Venice, in Muratori's words, from "archipelago" to "unitary" city, mirrored an economic transition from a feudal system of noble families each protecting their own island within the lagoon, to an open and necessarily interconnected merchant city. It is paradoxical 
but not coincidental that the designation of the Ghetto Nuovo as a locked island for the Republic's Jewish population occurred at the same moment that the city reconstituted itself with a more unitary city form. Francesco Erbani (2009, p. IX), in the preface to Mancuso's Venezia e una Citta, goes much further in calling the contemporary perception of Venice, a city of tourists, film festivals, and art biennales, "a metacity, a place that produces a clearly fake image of itself, a sneaky spectacular montage, a postmodern brand."

Near the coastal barrier island protecting the mouth of Venetian Lagoon into the Adriatic Sea, the island Lazaretto Vecchio served important functions for the maritime Republic between 1403 and 1630. Named after the biblical leper Lazarus, the island contained a leprosarium and hospital during plague epidemics. Importantly, it also served as an isolation station for ships arriving from plague infected ports. Ships were required to wait at anchor for forty days: quaranta in Italian, from which the word quarantine is derived. While rising sea levels and hordes of tourists now threaten the livability of Venice, fortified lagoon islands always protected the mercantile Republic, and lazarettos were invented to shield its citizens from foreign disease. The author of this essay, writing in self-quarantine, is practicing, like millions of others across the globe, social distancing in our homes; sanitary islands of safety from a viral pandemic outside the door.

\section{Archipelago as urban model}

On Sunday, August 13, 1961, the border between East Germany and West Berlin was closed. East German soldiers tore up streets and laid barbed wire along the entire $156 \mathrm{~km}$ perimeter in order to end mass emigration to the West. For architect O. M. Ungers, the newly appointed professor of architecture at the Technological University of Berlin, the isolation of the walled city - an island of democracy within a communist state - created the conditions to consider alternative models for the rebuilding of the post-war European metropolis. In West Berlin, architectural fragments from the many stages in the evolution of the modern European metropolis became an obsessive object of Ungers' study. West Berlin's status depopulated, fragmented, and walled - inspired not only important historical insights, but its unique insular political position induced novel contemporary design experiments as well. Ungers and his assistants published 27 pamphlets on architecture between 1963 and 1969, including studies of William IV's Havel landscape as a model in conjuring new fantastic possibilities for the "city within the city", islands of modernity and change within the fragmented metropolis of West Berlin (see Figure 3) (Mühlthaler, 2003).

Rem Koolhaas spent the summer of 1971 studying "the Berlin Wall as architecture" as part of his studies at the Architectural Association (AA) in London. There, he discovered the multiple pamphlets published by Ungers and his students:

[For Ungers,] Berlin is a laboratory. Its historical richness resides in the prototypical sequence of its models: neoclassical city, early metropolis, modernist testbed, war victim, Lazarus, Cold War demonstration, etc. First bombed, then divided, Berlin is now centerless, a collection of centers, some of which are voids. (Koolhaas, 1986, p. 449)

For Koolhaas, the wall was built to prevent East Germans' voluntary exodus to the hedonistic island of West Berlin. Upon returning to the AA, Koolhaas conceived a thesis 
project called Exodus, or The voluntary prisoners of architecture. The walled island of West Berlin served as an architectural model for his design of a series of walled utopic islands in post-war London. In Koolhaas' imagination, people would voluntarily segregate and imprison themselves in architectural enclaves to escape the deteriorating city and create a new urban culture in isolation.

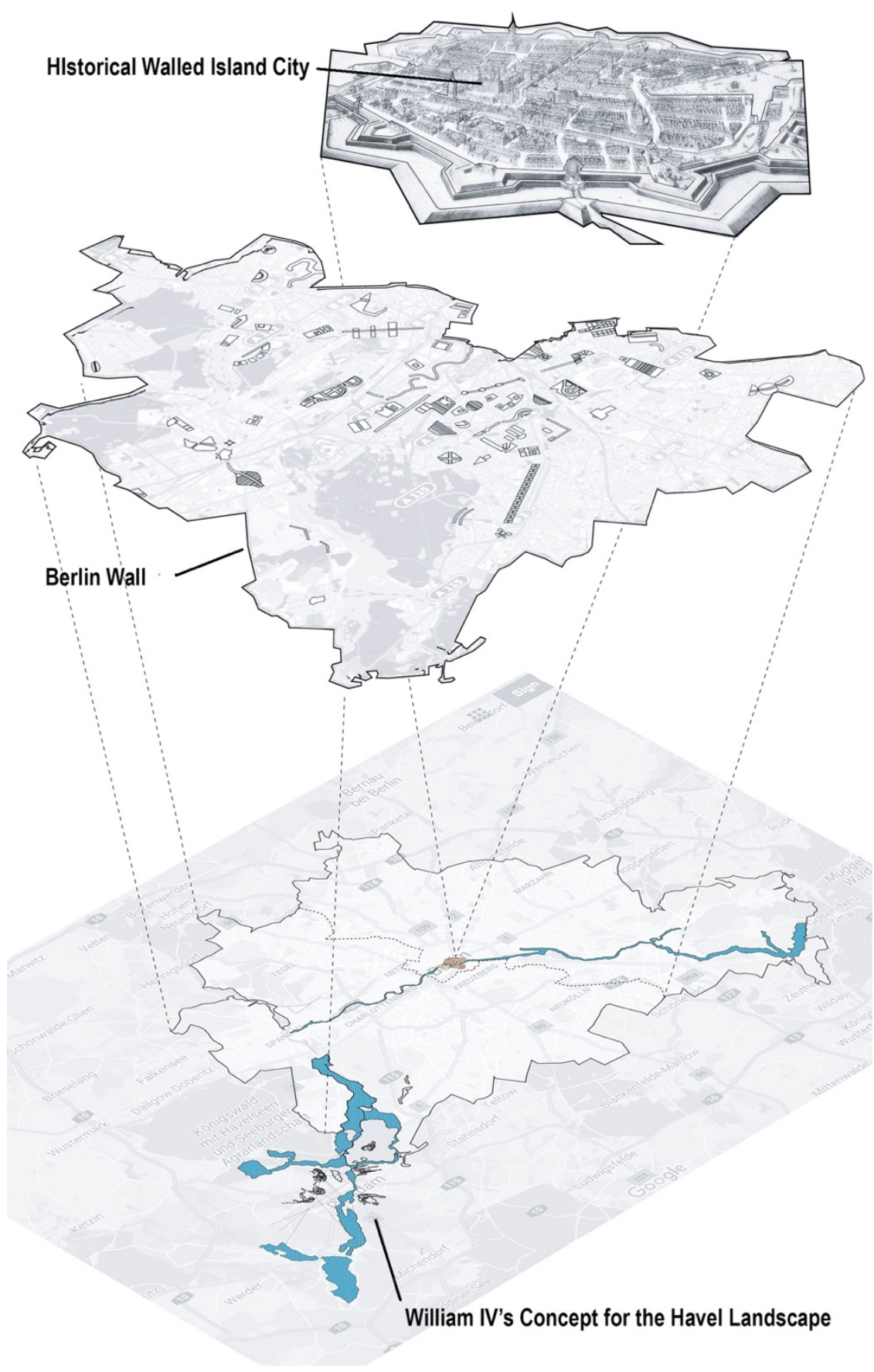

Figure 3: Berlin as Green Archipelago: Top, historical island city; middle, O.M. Ungers' cities with the city; bottom, royal forests surrounding Berlin, including William IV's Havel landscape design. Illustration: (C) Brian McGrath \& Tommy Yang. 
Upon completing his architectural degree, Koolhaas received a scholarship to study in the U.S. for two years, and sought out Ungers in his new position as the Chair of Architecture at Cornell University in Ithaca, New York. After years of collaboration, Koolhaas brought a short manifesto, Berlin: A green archipelago, to the first Cornell Summer Academy in Berlin organized by Ungers in 1977. Muratori's recent empirical identification of the real archipelago city in the Venetian Lagoon was transformed into a metaphor in naming Unger's experiments in West Berlin a "green archipelago" (Koolhaas, 1977). The manifesto calls, not for the rebuilding of Berlin, but for a "selective deflation of urban pressure," a "partial dismantling of malfunctioning parts" in order to "intensify and complete fragments that would be preserved [...] the remaining enclaves that are thus 'saved' and disengaged act like islands on the otherwise liberated plain of the city, and form an archipelago of architectures in a green lagoon of natures" (Hartweck \& Marot, 2013, p. 12). As Fritz Neumeyer writes, "the concept of the urban archipelago of architectural islands floating in a large context of 'nothingness' is the continuum of space was for Koolhaas, 'the absolute model' of the European city" (Neumeyer, 1990, p. 48).

Koolhaas discovered the use of Venice as a metaphor for a modern archipelago city during his research for his celebrated book Delirious New York (1994/1978). In the 1920s "Jazz Age", New York architect Harvey Wiley Corbett proposed a skyscraper city served by a system of elevated arched walkways over a ground plane devoted to automotive traffic. In order to solve the problem of congestion in Manhattan, Corbett envisioned "a very modernized Venice, a city of canals, plazas and bridges, with canals for streets, only the canals will [...] be filled with freely flowing motor traffic" (Koolhaas, 1994, p. 123). As an architect, Koolhaas was less interested in traffic planning than in the architectural possibilities of designing Manhattan's building blocks as islands. Like in walled West Berlin and his "Exodus" project for London, each block is an island on which to fulfill hedonistic metropolitan fantasies above and out of reach of the messy reality of the street.

In Corbett's 'very modernized Venice' each block has become an island with its own lighthouse. [...] The population of Manhattan - journeying from block to block would finally, and literally, become a metropolitan archipelago of 2028 islands of its own making. (Koolhaas, 1994/1978, p. 123)

According to Georg Simmel, from his observation of Berlin at the turn of the $20^{\text {th }}$ Century, the Metropolis produces a distinct mental life (Simmel et al., 1950/1903). Quoting Friedrich Nietzsche's description of Venice, Koolhaas (1994/1978, p. 120) sees New York as a city of "a hundred profound solitudes" based on its archipelago structure. Manhattan is an archipelago of "Paranoid Critical islands, insulated by neutralizing lagoon of the Grid" (Koolhaas, 1994, p. 274). The metropolitan archipelago model "implies an essential isolation: no longer does the city consists of a more or less homogenous texture - a mosaic of complimentary urban fragments - but each block is alone like an island, fundamentally alone" (Koolhaas, 1994, p. 97). This is not Jane Jacobs' (1961) community reinforcing New York street grid of brownstones, stoops, and corner hardware stores, but is a city of isolation, paranoia, and fear. Koolhaas celebrates one of the first buildings to fill an entire Manhattan block, the original Madison Square Garden. Constructed between $26^{\text {th }}$ and $27^{\text {th }}$ Streets on Madison Avenue to accommodate a hippodrome for the annual horse show (Koolhaas, 1994, p. 94), the original Garden was a decadent pleasure island for the gilded New York's turn of the century elite's top cultural event. 
Rossi's notion of the architecture of the city calls for "reading" of the city as a collective artifact without a distinction between nature and culture. Venice, as we have seen, is the quintessential example of island and archipelago as social-natural urban artifacts. Ungers developed the idea of a federation of cities within a city forming a green archipelago in the fragmented metropolis of West Berlin, with a similar figure of the architect as a careful and sensitive reader and researcher of history and context. In contrast, Koolhaas's "retroactive manifesto" of a metropolitan archipelago celebrates the interiority and isolation afforded by steel and glass islands within a sea of traffic, which he finally achieved in the CCTV tower in Beijing. The essence of Koolhaas' archipelago model is the power-projective role of the "metropolitan architect", who assumes formal control of design change within a structured grid. "The grid - or any other subdivision of the metropolitan territory into maximum increments of control - describes an archipelago of "Cities within Cities"' (Koolhaas, 1994, p. 95).

Koolhaas' nostalgic revival of the power-figure of the early $20^{\text {th }}$ Century metropolitan architect relies on technology to surpass the limits of nature. His "retroactive manifesto" provided a platform for his Office of Metropolitan Architecture (OMA) to gain commissions for large corporate, commercial and cultural enclaves around the world, which became the elite islands in the sea of neo-liberalism. The actual ecology of New York City or the "aquapelago" of the Hudson/Raritan Estuary (Hayward, 2015) was not of interest to Koolhaas, instead he imagined the gridded city of rectangular blocks containing metropolitan aeries above the sea of congestion below. For Aureli (2008, p. 108), Koolhaas' islands are architectural enclaves, not as in Unger's dialectical opposition to an outside green lagoon, but segregated from a hostile public. The enclave system of the gilded age has been revived for the contemporary city, where lavish interior worlds are created by 'starchitects' as shelters for elites within a contaminated world. While it is common for contemporary architectural fantasies to pay homage to the archipelago city (Bhatia \& Casper, 2013; Daou \& PérezRamos, 2016), few consider either the social-political context of these theories, nor the critiques of decolonization and denaturalization in Island Studies (Grydehøj, 2017).

\section{Archipelago as urban polity}

In January of 2012, an army of construction workers lowered hundreds of huge precast concrete slabs, enclosing a diffuse network of factory zones 60 kilometers north of Bangkok. Unlike the East German army's hasty construction to halt the flood of emigrants, these walls were hurriedly made to enclose multiple industrial estates before the onset of annual monsoon rains. The completed project created an archipelago of strangely shaped Berlin-like enclaves along the trunk canal that served as the eastern naval approach to the ancient island city of Ayutthaya, political inheritor to the Khmer Empire and conqueror of the Sukhothai Kingdom (see Figure 4). Rojana Industrial Park, home of one of Southeast Asia's largest Honda factories, is 7 kilometers due East of the archaeological treasures of Ayutthaya. Built over ten phases, Rojana consists of irregularly shaped raised islands of non-contiguous industrial zones, an assemblage of purchased plots within a sea of wet rice fields, where holdout farmers continue to flood and plow paddies to broadcast seeds and harvest rice. Canals, villages, and paddies form a fractal green lagoon entangled with factory enclaves now protected, like Sukhothai's royal enclave by a "triple walled flood protection system" (https://www.rojana.com/ayutthaya project.html). 
Six months earlier, on July 24, 2011, the powerful Typhoon Nock-Ten had formed east of the Philippine archipelago, and grew in strength over the following week. In the mountains of Northern Thailand near Sukhothai, Nock-Ten exhausted itself with a deluge of heavy rainfall flooding the Ping, Wang, Yom, and Nan River basins, swelling their smaller tributaries and filling their huge dammed reservoirs. Northern Thai cities such as Sukhothai were the first to flood, and while Ayutthaya was inundated, the residents of Bangkok in the lower delta, already water logged by the monsoon, awaited the outflow downstream. By midOctober, released water from overflowing reservoirs, together with additional heavy rains, inundated the already saturated rice paddies and orchards surrounding Bangkok. The water, trapped between Bangkok's protective dike and the continuous need to drain upstream regions, caused Thailand's worst flooding in over fifty years. However, fifty years previously, the Kingdom of Thailand was not an industrialized economy, and this flood, for the first time, now engulfed Rojana, the Honda factory and many other industrial estates. In total, seven, large industrial zones were under water, crippling the supply chain for automobiles throughout Asia, and for computer hard drives across the world. As Thomas Fuller (2011) reported, "The image of Thailand as a land of temples, [island] beaches and smiles has over the years been reinforced by the country's tourism advertising campaigns. But the flooding here $[\ldots]$ has revealed to the world the scale of Thailand's industrialization and the extent to which two global industries, computers and cars, rely on components made here."

What happens when "zones of exception", in this case the high-tech industrial estates which ring Bangkok, flood? For Keller Easterling (2014, p. 27), the "zone" is ancient and new, heir to the island free ports of antiquity such as ancient Delos. The royal island enclaves of Ayutthaya and Bangkok grew wealthy through their accessibility to trade between the Indian Ocean and South China Sea via the shortcuts through the meandering Chao Phraya River. The 2011 industrial zone flood brought the Kingdom of Thailand back to its historical cultural knowledge of island construction, and billions of dollars were spent to fortify an archipelago of industrial estates protected by massive moats and floodwalls. While the factory zones themselves have reverted to the most ancient Siamese defensive model of the royal island enclave, it remains to be seen how a dry land-based trucking infrastructure can continue to link the labor force to jobs and the industrial zones to container ports in an increasingly flood-risk "aquapelago" territory of the Lower Delta. Perhaps Thailand will return to the amphibious past of Southeast Asia celebrated by Sumet Jumsai and maintain barge links to deep-sea ports from an archipelago of urban islands in a rising sea.

Jumsai (1988) offers a compelling cultural reading of ancient Siam and the West Pacific, arguing that continental Southeast Asia and the archipelagos of Japan, the Philippines, and Indonesia share a water-based civilization comprising amphibious architecture and water towns, with Sukhothai as one of his primary examples. Through transoceanic and upstream migrations over eras of warming and glaciation, rising and retreating seas, "water people" maintained strong cultural affinities across a vast geography. Jumsai situates Siam's island cities within the historical logic of the archipelago, but the historical rise of Ayutthaya was tied to an agricultural (and now industrial) hinterland (Phongpaichit \& Baker, 2017, p. 83). The tributary political system underlying Sukhothai, Ayutthaya, and Bangkok emerges from these deep oceanic diasporic histories in cities designed as sacred island microcosms. Jumsai's oceanic philosophy for Southeast Asian urbanism is mirrored in an idea for the European city based on the political philosophy of Massimo Cacciari, who sees Europe as an archipelago of 
"irreducible plurality where the individual elements coexist as they are inevitably separated" (Viganò, 2012, p. 660). The Association of Southeast Asia Nations (ASEAN) is currently in search of a political and trade federation similar to the European Union.

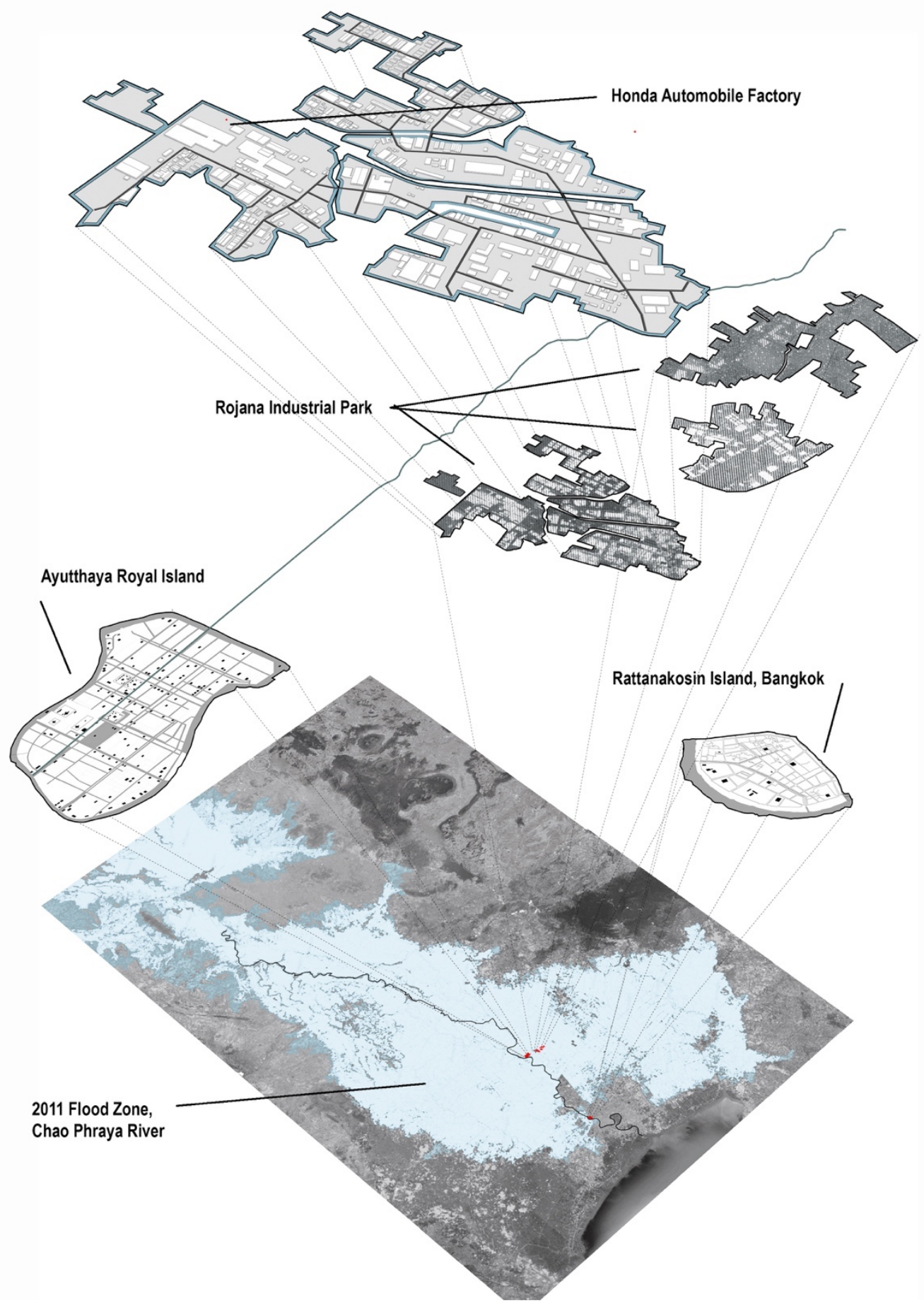

Figure 4: Archipelago as urban polity: Top, the Honda automobile factory within Rojana Industrial Estate; middle, the two island royal cities of Ayutthaya with three adjacent island industrial zones and Bangkok's Rattanakosin Royal Island; bottom, the Lower Chao Phraya Delta flood zone, 2011. (Illustration by Brian McGrath and Tommy Yang, 2020) 
Ancient Greece and the Aegean is Carriaci's geographic and political reference for European self-identification as an archipelagic federation rather than a unified continent in the post-Cold War era. For the Greeks, in Cacciari's view:

the sea represented a dangerous, seductive force that disrupted the primordial territorial basis of life-in-peace, the cosmic correspondence of a territory and a people $[\ldots]$ the sea is $[\ldots]$ a communicating bridge between multiple islands and insular languages. It is a medium in which the individual languages, local myths, and stories are collocated, compared, and confronted with one another. (Miller, 2014)

Cacciari was born in Venice and served two terms as mayor of the city from 1993-2000 and from 2005-2010. He sees Europe's lagoon not as blue or green, but as a political sphere for an archipelagic identity in departure from a history of conflict based on territorially grounded power.

Cacciari wishes to imagine an archipelagic form of community that is a contingent figure of relation traced by the "navigation" between places, between voices. 'Is it possible to conceive a community of islands in perennial navigation, each one awayfrom and towards (contra-versus) the other?' (Miller, 2014)

Ungers revised Koolhaas' green archipelago text under the new title City in the city as a policy proposal for the German Social Democratic Party to make Berlin the testing ground for an alternative model of urbanism (Hertweck \& Marot, 2013, p. 7). This new model is an archipelago of political islands floating in a green lagoon. Ungers did not share Koolhaas' paranoid viewpoint, but saw each island city within the city as an idealized independent fragment, yet part of a larger federative system.

\section{Conclusion}

Pier Aureli links Cacciari's political vision to Ungers' formal idea of the "city within the city". For Aureli (2008, p. 116), the green archipelago remains a valid meta-project for the contemporary city in that "a city that is no longer a continuous and ever-expanding network made by density and infrastructure, but rather a composition of formed, and thus limited, city-islands - of 'cities within the city'." Here, archipelago as model becomes the political essence of a decentralized democratic polity. Also inspired by Cacciari's political theory, architect Paola Viganò $(2012,2013,2018)$ argued for a modernist elementalism in designing the everyday urban territories of the post-Cold-War European city. Viganò's model is not Rossi's Venice, Ungers' Berlin, nor Koolhaas' Manhattan, but a “diffuse” (Viganò, 2012, p. 663) horizontal metropolis of roads, fences, canals, farms, factories, and commercial areas in peripheral areas such as the Veneto region west of Venice. In Archipelago city, diffuse city and reverse city (2012), Viganò's is a compelling counter argument to Koolhaas' islands as devices of social isolation or Allen's massive architectural landforms:

The concept of the archipelago explores the relationships between the fragments, expression of multiplicity and of distance between things that are irreducibly 
different. It seeks to establish not only the spatial characteristics, but also the social ones, of an aggregation of fragments. (Viganò, 2012, p. 660)

These fragments are assembled within "a space - or sea - of coexistence and of absence - the unity which was lost or never attained" (Viganò, 2012, p. 660).

Neo-liberal urbanization has dispersed hyper-concentration of islands for insider knowledge and hyper wealth among the "1\%" across the globe (Piketty, 2015). Doreen Massey provides a way of understanding how power is exercised in neo-liberal space as the result of "power-geometries" (2009). For Massey, neo-liberal space is a complex network, a multiplicity in the simultaneous coexistence of things and relations always in the process of being made (Massey, 2009, p. 17). Human societies understood the ability of island spaces to dictate the distribution of resources through distancing, separation, and segregation. This inventory of examples of island as urban artifact and archipelago as urban model presented here demonstrates the relationship to geometry-power-space. But this is only an introduction to Massey's more projective discussion: the project of building new power geometries for participatory democracies. Viganò's discussion of the archipelago, reverse, and diffuse city as an urban model aligns with Massey's project of the redistribution of power and resources in, I would argue, island and archipelagic space, through groups and affiliations, spatial continuity, neighborhood settlement, space of flows and relations, and seeing places are never homogenous and closed (Massey, 2009, p. 26).

McGrath and Pickett (2011) define the metacity as a conceptual framework for understanding socio-ecological relationships, adaptive processes, and power-geometries within specific neighborhood patches in all cities of whatever size and density, whether shrinking or growing, but within larger ecological frameworks and boundaries, such as watersheds. The metacity is a way of understanding any city as a patchy "system of systems" beyond Ungers' "cities within cities". Like Massey's redistributed power-geometries, metacity theory focuses attention on the spatial heterogeneity and dynamism of local patches, islands, and archipelagos, connecting these with regional fluxes that affect ecosystem health and enable citizen choice. These regional and local concerns are connected globally through virtual social networks, enhancing urban life through planetary stewardship (McGrath \& Pickett, 2011, p. 57). In ecology, a metacommunity consists of islands of the particular kind of community in question (McGrath \& Pickett, 2011, p. 59). Metacommunities are examples of spatial differentiation and partially discrete dynamics among the spatial isolates, the island to island relationships present in archipelagos. Thus, all islands and archipelagos, green, blue, and backwater, are cases of patch dynamic processes: the creation, alteration, and function of spatial heterogeneity through time (McGrath \& Pickett, 2011, p. 60). The architecture and the ecology of the metacity, therefore, is both a conceptual framework and a collective project for developing the logics of island as urban artifact and archipelago as urban model towards new socially equitable and environmentally resilient urban mosaics of meaning, inclusion, and belonging.

\section{References}

Abu-Lughod, J.L. (1989). Before European hegemony: the world system AD 1250-1350. Oxford University Press. https://doi.org/10.1086/ahr/96.4.1148 
Allen, S. (2011). From the biological to the geological. In S. Allen \& M. McQuade (Eds.), Landform building: architecture's new terrain (pp. 20-41). Lars Müller.

Aureli, P. (2008). Toward the archipelago. Log, 11, 91-120.

Baldacchino, G. (2006). Islands, island studies, Island Studies Journal. Island Studies Journal, 1(1), 3-18.

Baldacchino, G. (2004). The coming of age of island studies. Tijdschrift voor economische en sociale geografie, 95(3), 272-283. https://doi.org/10.1111/j.1467-9663.2004.00307.x

Barthes, R. (1970). Semiology and the urban, 1967 Lecture at the University of Naples, L'Architecture d'Aujourdhui 153 (December 1970).

Bhatia, N., \& Casper, M. (Eds.). (2013). The Petropolis of tomorrow. Actar Publishers \& Architecture at Rice.

Cœdès, G. (1968). The Indianized states of Southeast Asia. University of Hawaii Press.

Daou, D., \& Pérez-Ramos, P. (Eds.). (2016). New geographies 08: Island. Harvard University Graduate School of Design.

DeLoughrey, E. (2001). The litany of islands, the rosary of archipelagoes: Caribbean and Pacific archipelagraphy. ARIEL: A Review of International English Literature, 32(1), 2151.

Easterling, K. (2014). Extrastatecraft: The power of infrastructure space. Verso Books.

Fortis, U. (2000). The ghetto on the lagoon: A guide to the history and art of the Venetian ghetto 1516-1797 (Rev. ed.; R. Matteodoa, Trans.). Storti Edizioni. (Original work published 1987)

Fuller, T. (2011, November 7). Thailand flooding cripples hard-drive suppliers. The New York Times, 6.

Gómez-Barris, M., \& Joseph, M. (2019). Introduction: coloniality and islands. Shima, 13(2), $1-10$.

Grydehøj, A. (2017). A future of island studies. Island Studies Journal, 12(1), 3-16. https://doi.org/10.24043/isj.1

Grydehøj, A. (2015a). Island city formation and urban island studies. Area, 47(4), 429-435. https://doi.org/10.1111/area.12207

Grydehøj, A. (2015b). Making ground, losing space: land reclamation and urban public space in island cities. Urban Island Studies, 1, 96-117. https://doi.org/10.20958/uis.2015.6

Grydehøj, A., \& Casagrande, M. (2020). Islands of connectivity: Archipelago relationality and transport infrastructure in Venice Lagoon. Area, 52(1), 56-64. https://doi.org/10.1111/area.12529

Grydehøj, A., Pinya, X.B., Cooke, G., Doratlı, N., Elewa, A., Kelman, I., Pugh, J., Schick, L., \& Swaminathan, R. (2015). Returning from the horizon: introducing urban island studies. Urban Island Studies, 1, 1-19. https://doi.org/10.20958/uis.2015.1

Hay, P. (2006). A phenomenology of islands. Island Studies Journal, 1(1), 19-42.

Hayward, P. (2015). The aquapelago and the estuarine city: reflections on Manhattan. Urban Island Studies, 1, 81-95. https://doi.org/10.20958/uis.2015.5

Hertweck, F., \& Marot, S. (2013). The city in the city. Berlin: A green archipelago [Critical ed.]. Lars Müller Publishers. (Original work published 1977)

Herzfeld, M. (2012). The crypto-colonial dilemmas of Rattanakosin Island. Journal of the Siam Society, 100, 209-223. 
Herzfeld, M. (2002). The absence presence: Discourses of crypto-colonialism. The South Atlantic Quarterly, 101(4), 899-926.

Jacobs, J. (1961). The death and life of great American cities. Random House.

Johnson, H. (2020). Islands of design: Reshaping land, sea and space. Area, 52(1), 23-29. https://doi.org/10.1111/area.12477

Jumsai, S. (with Fuller, R.B.). (1988). Naga: cultural origins in Siam and the West Pacific. Oxford University Press.

Koolhaas, R. (2014/1978). Delirious New York: a retroactive manifesto for Manhattan. Monacelli Press.

Luo, B., \& Grydehøj, A. (2017). Sacred islands and island symbolism in Ancient and Imperial China: an exercise in decolonial island studies. Island Studies Journal, 12(2), 25-44. https://doi.org/10.24043/isj.19

Mancuso, F. (2009). Venezia è una città: come è stata costruita e come vive. Corte del Fontego.

Marshall, V.J., Cadenasso, M.L., McGrath, B.P., \& Pickett, S.T.A. (2020). Patch atlas: Integrating design principles and ecological knowledge for cities as complex systems. Yale University Press. https://doi.org/10.2307/j.ctvt1sg8j

Massey, D. (2009). Concepts of space and power in theory and in political practice. Documents d'Anàlisi Geogràfica, 55, 15-26.

McGrath, B. (2014). Backwater urbanism. In K. Hattam (Ed.), Backwater (pp. 19-24). La Trobe University Museum of Art.

McGrath, B., \& Pickett, S.T.A. (2011). The metacity: A conceptual framework for integrating ecology and urban design. Challenges, 2(4), 55-72. https://doi.org/10.3390/challe2040055

McGrath, B., \& Shane, D.G. (2012). Metropolis, megalopolis and metacity. In C.G. Crysler, H. Heynen, \& S. Cairns (Eds.), The Sage handbook of architectural theory (pp. 641-657). Sage.

McGrath, B., Marshall, V., Cadenasso, M.L., Grove, J.M., Pickett, S.T.A., Plunz, R., \& Towers, J. (2007). Designing patch dynamics. Columbia University Graduate School of Architecture.

Miller, T. (2014, March 29). From the Venetian to the European archipelago: The geofilosofia of Massimo Carriari. Crosspollenblog. https://crosspollenblog.wordpress.com/2014/03/29/from-the-venetian-to-theeuropean-archipelago-the-geo-filosofia-of-massimo-cacciari/

Mühlthaler, E. (2003). Learning from Ungers. Arch+, 181-182, 15-21.

Muratori, S. (1960). Studi per una operatante storia urbana di Venezia. Istituto poligrafico dello Stato, Libreria dello Stato.

Neumeyer, F. (1990). OMA's Berlin: The polemic island in the city [F. Rogier, Trans.]. Assemblage, 11, 37-53. https://doi.org/10.2307/3171134

Phongpaichit, P. \& Baker, C. (2017). A History of Ayutthaya: Siam in the Early Modern World. Cambridge University Press.

Pickett, S.T.A. (2012). Ecology of the city: a perspective from science. In B. McGrath (Ed.), Urban design ecologies: AD reader (pp. xx-xx). John Wiley \& Sons. 
Pickett, S.T.A., Cadenasso, M.L., \& McGrath, B. (Eds.). (2013). Resilience in ecology and urban design: linking theory and practice for sustainable cities (Vol. 3). Springer Science \& Business Media.

Pickett, S.T.A., \& Cadenasso, M.L. (2007). Patch dynamics: meaning, model and metaphor. In B. McGrath (Ed.), Designing patch dynamics. Columbia University Graduate School of Architecture.

Piketty, T. (2015). About capital in the twenty-first century. American Economic Review, 105(5), 48-53. https://doi.org/10.1257/aer.p20151060

Pugh, J. (2013). Island movements: thinking with the archipelago. Island Studies Journal, 8(1), 9-24.

Reynolds, C.J. (1976). Buddhist cosmography in Thai history, with special reference to nineteenth-century culture change. The Journal of Asian Studies, 35(2), 203-220. https://doi.org/10.2307/2053979

Rossi, A. (1982). The architecture of the city (D. Ghirardo \& J. Ockman, Trans.). MIT Press. (Original work published 1966)

Simmel, G., Bridge, G., \& Watson, S. (1950). The metropolis and mental life. In K.H. Wolff (Ed.), The Sociology of Georg Simmel (pp. 409-424). The Free Press. (Original work published 1903)

Stratford, E., Baldacchino, G., McMahon, E., Farbotko, C., \& Harwood, A. (2011). Envisioning the archipelago. Island Studies Journal, 6(2), 113-130.

Viganò, P. (2013). The elementary city. In B. McGrath (Ed.), Urban design ecologies (pp. 282299). John Wiley \& Sons.

Viganò, P. (2012). The contemporary European urban project: archipelago city, diffuse city and reverse city. In C.G. Crysler, H. Heynen, \& S. Cairns (Eds.), The Sage handbook of architectural theory (pp. 657-670). https://doi.org/10.4135/9781446201756.n39

Viganò, P., Cavalieri, C., \& Corte, M.B. (Eds.). (2018). The horizontal metropolis between urbanism and urbanization. Springer. https://doi.org/10.1007/978-3-319-75975-3 